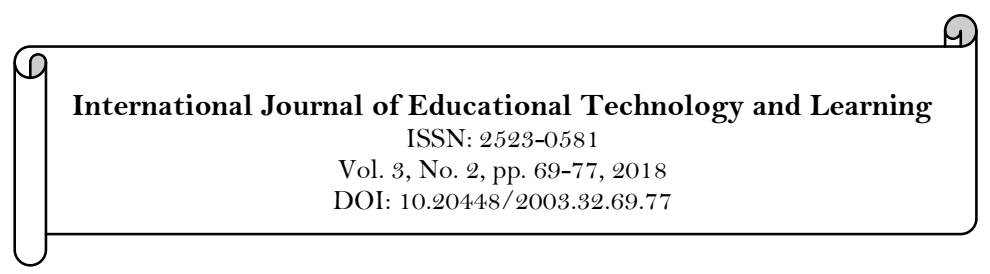

\title{
Study of Education Competency and Effect on Learning Process of BCCT Method on Educational Group of Education Age (PAUD) in Sukasari Bandung
}

\author{
Irma Yulisutiany ${ }^{1}$ \\ ${ }^{1}$ STKIP Sebelas April Sumedang Indonesia. \\ Email:correspondent.author@gmail.com
}

\begin{abstract}
The purpose of this research is to describe the objective condition of PAUD Kober Nurul Huda. Describe the level of competence that educators have. Describe the application of learning through the BCCT Method. Know the influence of the application of learning BCCT Method. The research method used is a qualitative method of research subject is Kober Nurul Huda. Data collection methods used are methods of observation, interviews, and documentation. The conclusion of this research is the objective condition of PAUD Nurul Huda has the strength which generally comes from facility, location, and education of the educator, weakness is found in the competence of educator in giving learning of BCCT, opportunity to potential of parent desire to send their child to PAUD applying BCCT , and threats from environmental influences that are contrary to the concept of BCCT itself. The competencies of PAUD Nurul Huda educators include pedagogic competence, personality competence, physiological competence, but generally still weak on social competence. The application of learning through the BCCT method of Kober Nurul Huda can optimize all aspects of children's development, whether physical, emotional, cognitive, and social. The influence of learning through BCCT methods of learners is seen primarily in the moral and religious values, cognitive learners, the use of everyday language, the emotional social of children, creativity, the soul of art, and life skills. The recommendations proposed are practical, the playgroup Nurul Huda should make education more creative in providing learning, educators need to develop and practice in running learning, the foundation should provide facilities to educators to include them in BCCT training held Diknas city or province. Theoretically, developing theories about the aspects of the learner, so the results of this study can develop the success rate of learners together with the discipline of psychology.
\end{abstract}

\section{Introduction}

Currently, there is a method of learning that is used for early childhood in the form of learning comprehension to play in various ways. One of them is by using Beyond Center and Circles Time (BCCT). West Java Province is the province with the highest number of PAUD and BCCT users in Indonesia (Ziegler, Bremer, \& Krämer, 2010).

Beyond Center and Circles Time (BCCT) is a method or approach in the implementation of early childhood education. This method is developed based on the results of theoretical studies and empirical experience which is the development of the approach of Montessori, High / Scope, and Reggio Emilia. This method was developed by the Creative Center for Childhood Research and Training (CCCRT) Florida, USA and implemented in Creative Pre-School Florida, the USA since the 80s, both for normal children and for children with special needs. BCCT method is done through the educative game. Its use is considered to give a positive contribution to the success of children's learning. BCCT is effective in applying to learn in early childhood, partly because it is done with the game so that children feel happy for doing the learning activities (Cardosos, Cardoso, Oliveira, \& Gouveia, 2016). 
According to government regulation No. 19 of 2005 on the national standard of education which one of them covers educator standard and educational staff, an educator, in an educational activity, must have academic qualification and competence according to his study of science which includes pedagogic competence, personality, and social competence. Training for PAUD Educators to be an alternative activity in an effort to increase academic qualification and competence of educator in applying learning method of BCCT at early childhood. Therefore, PAUD educators in Bandung City, coordinated by DEPAG and DIKNAS, strive to always make an effort to improve the quality of PAUD educators, not least in PAUD BCCT organizers of Sukasari District which became the object of this study .

PAUD's objective conditions of strengths, weaknesses, opportunities, and threats will demonstrate the influence of family and school environments, government regulations, and policies, and can identify the needs of early childhood learning so that learning by BCCT method becomes more effective.

The competence of early childhood educators in supporting early childhood learning is very important, because, in early childhood education, the principle of learning applied is (Oliveira, Magalhães, Cardoso, \& Cardoso, 2010) through playing while learning, learning while playing aims to build the potential for the child.

Application of learning through a BCCT method of early childhood is expected to contribute to improving children's development as well. The development of a child changes physically, intellectually, socially and emotionally through the execution and achievement of the child's developmental tasks (Cardoso, Pinto Da Costa, \& Cardoso, 2005).

By using the BCCT method or the center and circle approaches, the competence of educators is believed to improve the effectiveness of learning. Therefore, since PAUD educators as spearheads that move in the field become one of the elements that must be considered both quality and quantity, the training program with BCCT / circle center approach, is one of the important programs aimed at PAUD educators to improve competence pedagogic, personality, social, professional and performance of PAUD educator in carrying out its role and duty in educating the learning community, besides with approach of center and circle of students will be more explored its development potential, because with BCCT the child will be more focused again on the learning given in schools and children will not experience boredom, when the circle of children will be directed at every activity, and learning games also in accordance with the interests of children and not in each child to apply to all activities provided by educators (Ika, Maryatun, Kunci, Paud, \& Anak, 2016).

\section{Literature Review}

\subsection{A story of PLS Learning Theory}

On the outside of school education is more oriented to the needs of learning, which is closely related to the needs of education and living needs, resources and potentials available, as well as possible barriers in learning activities. The learning program emphasizes the interests in the community and the local area. The program is flexible, while the implementation of the program prioritizes the participation in all parties related to the interests of the people, the scope and the nature of non-formal education. This provides space and time for educators to involve themselves in the planning, implementation, and evaluation activities of learning (Unity Asset Store, 2014).

\subsection{The Concept of Early Childhood Education}

PAUD as education held before the level of basic education has a target group of children aged 0-6 years which are often referred to as the golden period of development. Therefore, the implementation of childhood (Suryono \& Fauziah, 2015) should pay attention and in accordance with the stages of child development. PAUD program is not intended to steal what start should be obtained at the level of basic education, but to provide appropriate educational facilities for children, so that children in time have the readiness, both physically, mentally, and socially / emotionally in order to enter more education continue (Murad, Kusniawati, \& Asyanto, 2013).

\subsubsection{Basic Philosophy of Early Childhood}

Differences in the philosophy embraced from a nation will bring a difference in orientation or educational goals. Indonesian people that embrace the philosophy of Pancasila believes that the formation of human Pancasila is into the orientation of the goal of education is to make a whole Indonesian man. The Indonesian nation also highly appreciates the difference and loves the democracy embodied in the motto of Bhinneka Tunggal Ika which means "different but one." From the slogan, the Indonesian people also highly uphold the rights of the individual as a creature of God that can not be ignored by anyone. Children as individual beings are also entitled to get an education that suits their needs and abilities (Kristanto \& Karmila, 2011).

In relation to the philosophical view of the curriculum as a tool for achieving the objectives of education, its development should pay attention to the philosophical view of the nation in the process of education that took place. 


\subsection{Principles of Early Childhood Education}

The basic principles of early childhood education made are as follows: a). orient to the needs of children. b). learning activities are done through play. c). stimulate the emergence of creativity and innovation, creativity and innovation. d). providing an environment that supports the learning process. e). develop life skills of children, life skills directed to help children become independent, discipline able to socialize, and have basic skills useful for life later. f). using various sources and learning media that exists in the environment. $g$ ). implemented gradually and repeatedly with reference to the principles of child development. h). educational stimulus is comprehensive that covers all aspects of development (Diana \& Health, 2011; Ika et al., 2016).

\subsection{3.. Principles of Child Development}

Children will learn well if their physical needs are met and feel safe and comfortable in the environment. Children learn continuously, starting from building an understanding of something, exploring the environment, rediscovering something concept, to be able to make something valuable, learn through social interaction, both with adults and with peers. Child's interest and persistence will motivate children's learning. Child development and learning styles should be considered as individual differences. Children learn from simple things to complex from concrete to abstract, from movements to verbal language, and from oneself to interaction with others (Lindawati, 2012).

\subsection{The Concept of Educator Competency}

Competence is the ability to implement something gained in education and or training. Competence refers to a rational act and meets certain specifications in carrying out educational tasks. Teacher competence includes; (1) mastering materials included in the study of a lesson, curriculum, and supporting learning. (2) managing the teaching and learning program includes the formulation of learning objectives, using the method, implementing the learning program, recognizing the ability of students and provide remedial for students in need, (3) manage the class include: organize the classroom, the climate in the classroom to create the KBM (5) mastering the educational foundation of both psychological, sociological, and historical concepts, (6) managing the teaching and learning interaction, (7) using the media sources, including: knowing, choosing and making aids, using library laboratories and other facilities. ) assessing student achievement for teaching purposes, (8) implementing counseling program, (9) organizing school administration, (10) managing learning outcomes. Thus, the competence of teachers is crucial to supporting the success of work and facilitate the daily profession in school. Competence is a tool of legitimation of the teaching profession so it is easy to distinguish between professional teachers and non-professional teachers (Ramadoni \& Imron, 2016).

\subsection{Theory of Early Childhood Learning Program}

Early education is more concerned with the learning process of playing and playing while learning, and each child basically has its own uniqueness through PAUD education. This is the uniqueness that we can explore. Minister of National Education hopes the development of early childhood education, especially nonformal early childhood, always refers to the strategic plan of Depdiknas (Campello, 2006) ea (María Viedma Marti, 2004) c (Murphy, 2005). Non-formal PAUD is spread in the form of Child Care Park, Play Group and similar early childhood and infant school. Similar PAUD Units includes Bina Balita, Qur`an Education Park, and Sunday School.

Flexible, good place to learn/does not have to be a separate and permanent building, study time and curriculum (government only gives signs). Not strictly limiting the academic requirements of educators (especially in the early stages), there is an important willingness to improve knowledge/skills in the area of ECD. Empowering all potentials (SDM / SDA) in the community so that the existence of early childhood is very helpful for the community, especially those who can not afford to send their children to kindergartens whose cost is relatively very expensive.

\subsection{The Theory of the Application Process of BCCT Learning}

BCCT in Indonesia is popularized by the term SELING (Sentra and Circle). This method is suitable for very diverse Indonesian conditions because it prioritizes local excellence and culture. BCCT is only one of the methods recommended by MoNE. Implementation of early childhood in the field may take another approach as long as according to the principles of early childhood (Anwas, 2012). BCCT is considered the most ideal applied because it is able to stimulate all aspects of intelligence (multiple intelligent) children. The learning sett is able to stimulate the child to be active, creative and keep thinking about digging his own experience and knowledge (not just following orders, imitating or memorizing). In addition, BCCT uses standard operating standards, centered on activity centers, and when children are in a teacher's circle, making it easier to follow especially for beginners. In this approach, the curriculum used is based on the assumption that children learn through playing with objects and the people around (people and the environment). In to play, children interaction with humans and the environment, so that children can grow and develop optimally because it can influence from the environment (Anwas, 2012). 
BCCT is developed based on the results of theoretical studies and empirical experience. BCCT is the development of the Montessori method, high, and Reggio Emilio. BCCT a concept of learning that teachers present the real world into the classroom and encourage students to make connections between the knowledge possessed by its application in their daily lives (Kristanto \& Karmila, 2011).

BCCT is designed in the form of centers eg; center on nature, micro role play center, center on macro role play. design center, preparation center, Imta center, art and creative center, music center and body center, IT center, and others. Each center supports 3 types of play (play of motor sensor, play role, play development). The teacher is responsible for 10 students only with moving class, in accordance with the burn centers. BCCT sees play as the most appropriate vehicle for the methods that exist because in addition to fun, playing in educational settings can be a vehicle for creative thinking, creative and responsible (Cardosos et al., 2016).

\subsection{BCCT in the Center}

Various centers can be applied to the learning of BCCT, such as the center of natural materials, the central role of macro and micro, block centers, preparation centers, faith centers and taqwa, art and creativity centers, music and cultural centers and so forth (Ziegler et al., 2010).

Introduction to each center. Sentra is a learning method in which each teacher collects 5-6 children (ideally). Here the child does his own experiments, the teacher guides the child by providing materials and instructs and observes the child's activities and assesses his progress (Permana, 2015).

Sentra allows children to manipulate objects, engage in role-playing, talk to each other with friends, explore, interact physically, emotionally, socially and cognitively and with other interesting variations. Sentra provides opportunities for children to play, individually, small groups or large groups and even the classical children are allowed to choose interesting activities for him, and eventually, the child will make it as an active and interactive learner (Suryono \& Fauziah, 2015).

\subsection{Application of BCCT Centers}

In each center developed various aspects of the development of religious values, cognition, effectiveness, language, social, emotional, art and psychomotor, to explore the potential development of students.

\section{1) Natural Language Center}

The goal is to introduce and nurture the sensitivity of children that the materials that exist in the natural environment and the immediate environment of the child, can be a source of knowledge that supports experimental activities and exploration of fun children. The playground while learning to develop a sensorimotor experience in order to strengthen three fingers for the preparation of writing, as well as the introduction of science. Expected Effect: The child can be simulated motor aspect should optimally and know science early on (Ika et al., 2016).

\section{2) Micro Role Main Center}

The goal is to develop the power of thought and the ability of imagination (creativity) so that children can pour their sensory experience in playing symbolic (fantasy game). A playground while learning, where children can develop imagination and express the feelings of today, yesterday, and the future. The emphasis on this center is on the storyline so that children are accustomed to thinking systematically. Expected effects: children can socialize and interact with friends and the environment and develop the ability optimally (Ika et al., 2016).

\section{3) Preparation Center}

The goal is to introduce basic concepts of listing (reading, writing, and arithmetic) simply by using easyto-understand symbols to prepare children to explore learning in school. A playground while learning to develop a literacy experience. In this center, the children are facilitated with games that can support the reading, writing, counting experience, which are in demand. Expected effects: children can think regularly, enjoy reading, writing and counting (Imanudin \& Imron, 2014).

\section{4) Beams Center}

The goal is to stimulate and foster the creativity of children according to his imagination. The playground while learning to present the idea of the real form (wake up). In this center, a child can play beams with a ratio of 1 child +100 beams plus accessories. This center emphasis on start and finish, where the child takes the beam as needed and returns it by classifying it based on the shape of the beam. Expected effects: children can think typology, know space and shape so as to develop visual intelligence spatial optimal and children can recognize forms of geometry that is very useful for basic knowledge of mathematics (Kristanto \& Karmila, 2011). 


\section{5) Faith and Taqwa Center}

In this center, it is expected that children can perform daily praying habits such as reading a prayer before and after activities, training patiently in queuing for hand washing, whose purpose is to increase the child's devotion to God Almighty and inculcate moral values in early. Playground while learning to develop physical intelligence where physical activity is more focused on religious activities. In this center, children are facilitated with play activities that focus on the habit of worshiping and knowing the letters hijaiyyah by playing while learning. Expect effects: Embedded behavior akhlakul karimah, sincere, patient and happy to run the religious command (Diana \& Health, 2011).

\section{6) Center for Art and Creativity}

Its purpose is to introduce and stimulate the ability of various art and culture. A place to play while learning that focuses on the ability of children in creating. Activities in this center are implemented in the form of projects, where children are invited to create certain creations that can produce a work. Expected Effects: Children can think creatively (Ika et al., 2016). The praise of the environment towards the work produced by the child will strengthen his confidence. With the art of children can work together in a group of planning, decision making, then make it happen in real form. This art activity can develop children's social for Music and Culture.

In this center is expected to children can follow the activities about the introduction to musical instruments and songs from various local areas through the media images. Can also sing together by listening to music. Playground while learning to introduce a variety of musical instruments, especially traditional music, and traditional games from various regions (Myers, 2001).

\subsection{Important Things in Sentra}

An arrangement of the main environment and the arrangement of areas where children play in the circle, such as language centers, cognitive centers, science centers, art centers and others. In this center is expected that children are able to develop their potential in accordance with what is expected of educators, as well as parents. Proper placement of the playground enables the child to be independent, disciplined, responsible, initiating and ending play, classifying. Determination of play tools and materials support the child making his own decisions, developing ideas, pouring ideas of concrete work, developing social skills (Lindawati, 2012).

\subsection{Rules of Each Center}

Center Prepare its purpose; introducing basic concepts, listing (reading, writing, and arithmetic) simply by using easy-to-understand symbols to prepare children to explore learning in school.

\subsection{Intensity and Density}

Intensity is the amount of time it takes for a child to experience three types of play throughout the day and throughout the year. Example: Children are allowed to choose from a series of daily activities that provide opportunities to engage in motor roles, development, and sensory. The concept of intensity emphasizes the number of time children needs to move through the necessary stage of cognitive, emotional, and physical development (Permana, 2015).

Density is a variety of ways each type of play is provided to support activities. Example: The child can use paint on the board, a finger paint tray, paint with a small brush on the table, and so on, to practice the skill of developing a liquid nature. Children can use to beam units (Pratt), hammers with nails and wood, remnants of building materials with glue firepower, and lego TM for practicing structured development skills. The concept of density emphasizes different activities, provided for children by adults provided for an early age. These activities should enrich the opportunity for the child's experience of three types of play and chosen according to the child's interests and developmental needs (Putra, Nugroho, \& Puspitarini, 2016).

\subsection{Daily Development Observations}

The development of daily observation is anecdotal notes and direct observation during the child follow activities in each center. Observations mainly on the development of moral values, language, mathematical logic, kinesthetic, psychical, art and culture, life skills ((Putra et al., 2016).

\subsection{Early Childhood Education as a Form of Outside School Education}

PLS program under Depdiknas, one of them is Early Childhood Education (PAUD). Early in its development, the PAUD program is aimed at mothers with children under five, with the provision of knowledge and skills to mothers to establish coaching programs, and guidance to children, so that children can grow and develop, optimally. This program actually has been started since the eighty years known as Bina Toddler Program (BKB) under the guidance of the State Minister for the Role of Women's Role or now BKKBN. Then this activity is carried out by NGO, PKBI with children activity in playgroup (Ika et al., 2016). 


\section{Research Methods}

In accordance with the substance of the problem, this research uses a qualitative approach, namely research aimed at understanding social phenomena from the perspective or perspective of participants. Participants are people that are invited to interview, observation, asked to provide data, opinions, thoughts, perceptions. Understanding is obtained through the analysis of the interrelationships of participants, and through the deciphering of "participant meaning" about situations and events.

This qualitative research examines perspectives of multiple strategies. Interactive strategies, such as direct observation, participatory observation, in-depth interviews, documents, complementary techniques, such as photographs, recordings, etc. The research strategy is flexible, using various combinations of techniques to obtain valid data.

The research instruments are as follows Table 1:

Table-1. The grid of Research Instrument Preparation.

\begin{tabular}{|c|c|c|c|}
\hline Variables & Sub Variables & Dimension & Source of Data \\
\hline $\begin{array}{l}\text { 1. Educator } \\
\text { Competencies: } \\
\text { 1.1. Learning BCCT. } \\
\text { 1.2. Development of } \\
\text { learning facilities. } \\
\text { 1.3. Extracurricular } \\
\text { activities. }\end{array}$ & $\begin{array}{l}\text { - The educator creates a learning plan } \\
\text { as required, } \\
\text { - Educators use various learning } \\
\text { methods and media. } \\
\text { - Educators evaluate the process and } \\
\text { learning outcomes of BCCT in early } \\
\text { childhood. }\end{array}$ & $\begin{array}{l}\text { Educator/Teach } \\
\text { er }\end{array}$ & $\begin{array}{l}\text { Observation } \\
\text { Structured }\end{array}$ \\
\hline $\begin{array}{l}\text { 2. Principal } \\
\quad \text { Participation } \\
\text { 2.1.tv } \\
\text { 2.2.Principal } \\
\quad \text { Participation }\end{array}$ & $\begin{array}{l}\text { - Headmaster has a planned learning, } \\
\text { means of educational infrastructure. } \\
\text { - Principals assist educators in the } \\
\text { development of learning through } \\
\text { BCCT } \\
\text { - The principal evaluates the BCCT } \\
\text { method that educators have taught }\end{array}$ & $\begin{array}{l}\text { Educator } \\
\text { Teacher / } \\
\text { Headmaster. }\end{array}$ & Observations \\
\hline $\begin{array}{l}\text { 3. Implementation of } \\
\text { school programs. } \\
\text { 3.1. Annual Program } \\
\text { 3.2.Program Semester. } \\
\text { 3.3.Program Weekly. } \\
\text { 3.4.Program Daily. }\end{array}$ & $\begin{array}{lll}\text { - } & & \\
\text { Educators } & \text { create an annual, } \\
\text { semiannual, } & \text { weekly program in } \\
\text { providing } & \text { learning } \\
\text { childhood. } & & \end{array}$ & Headmaster & $\begin{array}{l}\text { Observation } \\
\text { and } \\
\text { Documentation. }\end{array}$ \\
\hline
\end{tabular}

Source: Cardoso et al. (2005)

\subsection{Data Collection Techniques and Instruments}

Library research is used to obtain secondary data, ie searching materials and theories by studying, researching, reviewing, and reviewing the literature related to the issues to be studied about teacher competence and learning of BCCT application for Children Early age.

Field research used to obtain primary data, by visiting teachers/educators and principals PAUD in District Sukasari concerned to make a direct observation of the activities undertaken in the early childhood.

\subsection{Data Analysis Technique}

According to Ramadoni and Imron (2016) the data onto qualitative research is generally a qualitative descriptive narrative if there is document data analysis in the form of qualitative narrative, looking for similarities and differences of information, Data analysis in qualitative research is not expected until all data collected, but done gradually after completion of a collection of data onto the results of interviews, observations and documents, interpretation is directed at finding the essence of things that are fundamental from reality.

\subsection{Data Credibility}

The extension of participation in the field in the credibility of the data requires observation and extension of observations in data coverage and the participation of researchers in the research site, the extension of the participation of the researcher will enable increased confidence in the data and information collected. Peer checking through discussion. Conducting discussions of colleagues that know the research sites and also resource persons that play a role in the daily activities of the research site. 
Reference sufficiency. Analysis using references serves as a comparison of theoretical to the truth about data and information obtained in the research site, This is done through the presentation of data and information conducted by PAUD educators in the learning process.

Member Checking. In this study researcher as a key instrument, still partnered with early childhood, and leaders of playgroups to obtain data on early childhood development.

Criteria of dependence. The auditor strives to meet the benchmarks, whether the inquiry decision and methodology is found, checked and supported, researchers' skewers is also examined to apply to the extent to which the researcher is too quick to end a data collection activity this is necessary because the researcher believes in his apriority knowledge. Certainty criteria by using auditing techniques in this study are to check the reliance and certainty of data and information has been how far has been collected and how availability of data and information at the source.

\section{Research Result}

The results of this study reveal the facts that exist on the field during the researchers conducted observations, interviews and documentary studies in the group playing Nurul Huda Sukasari sub-district ie :

1) The learning process of BCCT differs from conventional learning, in BCCT learning the children find themselves the type of play that will be done, so that in one day of learning each child will produce different works, the child can do more than one play activities, provided that finish the game first / his first activity.

2) Educators serve as mentors, caregivers, facilitators, directors and motivators, but after conducting indepth interviews it is implied that they are better equipped to teach in a conventional fashion, that all children do the same activities and the same place, targeted and easy to be in condition, educators feel the limited of manpower, time, knowledge, and skill to apply the optimal learning of BCCT, this is cause educator understanding about BCCT still need guidance of applying BCCT learning process correctly, and limitations in allowing for the preparation of BCCT facilities, such as certain centers are still lacking in the theme of learning, facilities and inadequate suggestions in the application of BCCT learning process, the number of students who many while educators still not handle it optimally, making it difficult to observe $\mathrm{k}$ all children individually in a single activity. The timing of activities that have not been optimal and felt too less in because sometimes the presence of children that are late, so that the time activities that have been set not achieved, the condition of playing each center are less extensive than the number of children so that children are less flexible in the move.

3) However, based on observations and interviews of educators, children and parents, it appears that BCCT learning process of beginning to end can stimulate the six aspects of child development and improve the creativity of children both cognitive and affective aspects, seen from many creative ideas of children, dare to answer questions which are proposed by educators and researchers, think smoothly, think flexible, curiosity is high, happy to try everything, trying continuously / diligent and successful.

4) Respondents Ariq, Zaldi, and Hasna all have their cognitive and affective creative traits well developed, visible from their work and spontaneous answers, as well as unique ideas, and overall every child has improved in many ways after following learning BCCT.

5) In addition, the researchers did not see the cooperation of teachers in applying the BCCT learning, to their students, and in preparing facilities and infrastructure of BCCT when the lesson took place, also the researchers did not see the nameplate of the group playing Nurul Huda in front of the school, is because this playgroup joined Raudhatul Atfhal, for a child who has been able to continue in elementary school.

\section{Conclusions and Recommendations \\ 5.1. Conclusions}

1. The objective condition of PAUD Nurul Huda in Sukasari district is seen from the strength of having a strategic place, in the middle of the housing complex so that children are safe to play and learn not noisy with vehicles, and good buildings, conducive and strategic environment and excellent human resources, which requires guidance and direction for further development and good cooperation with related levels such as the Himpaudi Early Childhood Educator Association is good enough, the weakness for the lack of competence of educators in providing BCCT learning to students so that educators only apply conventional methods of the learning process that takes place, good cooperation should be improved with both other educators, parents, and children who educated, so as to create a good learning process. The chance is actually if the BCCT learning is in good order then many parents who want to send their children to the Nurul Huda playgroup and the threat if BCCT learning is not implemented properly then the chances of the child will be less in the development of its potential and limited to what the instructor instructed, so the child will be a child who is not creative especially if BCCT learning is only in the will of educators only. 
2. The competencies of PAUD Nurul Huda educators are gained in training and competence in the form of skills, knowledge, which are owned by Early Child educator such as pedagogic competence, educator already understand the characteristics of each student, and understand the basic of education, master the principles and play approach for children, provide guidance. Personality competence, educator already has a sensitivity to the feeling and mind of his / her students can appreciate the difference and uniqueness of the individual and quickly respond to the difficulties of the students, have a sense of affection to the students responsive and motivate the child, have patience, flexibility, honesty and attention objective. Professional competence, educators have mastered the children's physical, social and emotional oriented learning menu, language and art of children skills, understanding the development of learning themes can master the development of programs in accordance with the needs and development of students as it can design the program semester, weekly program and daily program. Social competence, educators have enough understanding of children in the context of kinship, culture and surrounding communities, able to communicate with children can work together with parents, government and surrounding communities for educational purposes. The PAUD educators Nurul Huda also already has educator certification standards.

3. The application of learning through the BCCT method of early childhood has a very important role in human resource development, the provision of early childhood education in early childhood Nurul Huda already have a fairly precise approach, so as to optimize the potential for all children, especially in jumping all potential intelligence of children, there are many approaches in early childhood education, such as BCCT or center and circle approach, the BCCT approach is based on the assumption that children learn through playing with objects and people in their environment, in playing children with the environment, appropriate play can optimize all aspects of child development, both physical, emotional, cognition, and social children.

4. The influence of learning through the BCCT method of early childhood is seen from the results of its learning evaluation based on children's play activities in accordance with the stages of child development, this approach has shown to parents how important to play sensorimotor, role play, playing development until the emergence of literacy, PAUD educators, managers, and other education personnel and parents have a very big influence over the application of this BCCT learning, to realize the learning process is fun, fun, and educational, BCCT to help all parties who want to learn and try to apply it in the surrounding environment.

\subsection{Recommendation}

1. Nurul Huda plays groups should make education more creative in providing learning such as the computer by making annual, semiannual, weekly and daily learning plan format already available in school educators need to develop and practice in learning that walking difficulty getting references about learning methods BCCT in district Sukasari is a good foundation to provide facilities to educators to include educators in the training and development of BCCT held Diknas city or province.

2. The results of this study contribute theoretically, namely to provide the development of existing theories, namely to develop aspects of the child, such as aspects of cognitive, language, psychomotor, physical, emotional social, creativity, moral and religious values, and life skills. So the results of this study can develop the success rate of students together with the discipline of psychology.

\section{References}

Anwas, O. M. (2012). Posdaya model as an alternatif operational for early childhood education society based. Journal of Education and Culture.

Campello, M. (2006). Asset tangibility and corporate performance under external financing asset tangibility and corporate performance under external financing. University of Illinois at Urbana-Champaign. Retrieved from https://doi.org/10.2139/ssrn.971170.

Cardoso, J. S., Pinto Da Costa, J. F., \& Cardoso, M. J. (2005). Modelling ordinal relations with SVMs: An application to objective aesthetic evaluation of breast cancer conservative treatment. In Neural Networks.

Cardosos, M. J., Cardoso, J. S., Oliveira, H. P., \& Gouveia, P. (2016). The breast cancer conservative treatment. Cosmetic results - BCCT.core - Software for objective assessment of esthetic outcome in breast cancer conservative treatment: A narrative review. Computer Methods and Programs in Biomedicine.

Diana, M., \& Health, O. (2011). Integrated paud. Differences in Child Growth in the Integrated Health Post for Posyandu with the Integrated Health Service Post is not Integrated.

Ika, O., Maryatun, B., Kunci, K., Paud, P., \& Anak, K. (2016). The role of education educators in building children's character. Children's Education Journal.

Imanudin, D., \& Imron, A. (2014). Relationship between parents and early childhood education institutions. Educational Technology Students.

Kristanto, K. I., \& Karmila, M. (2011). Identification of child friendly school models (Sra) level of early childhood education unit in semarang districts. PAUDIA Research Journal.

Lindawati. (2012). Factors relating to motor development in pre-school ages. Health Quality Journal. 
María Viedma Marti, J. (2004). Social capital benchmarking system: Profiting from social capital when building network organizations. Journal of Intellectual Capital, 5(3), 426-442.

Murad, D. F., Kusniawati, N., \& Asyanto, A. (2013). Application of intelligence website to support the PAUD Report on the Huluhudi of Tangerang City. Dina Fitria Murad, Nia Kusniawati, Agus Asyanto.

Murphy, P. (2005). Education, educators and financing modalities: Reflections on experience in Uganda. Journal of International Development, 17(1), 131-147.

Myers, S. C. (2001). Capital structure. Journal of Economic Perspectives, 15(2), 81-102.

Oliveira, H. P., Magalhães, A., Cardoso, M. J., \& Cardoso, J. S. (2010). An accurate and interpretable model for BCCT.core. Retrieved from https://doi.org/10.1109/IEMBS.2010.5627778

Permana, S. D. H. (2015). Development of android game applications for the introduction of color patterns in Posdaya District. Infotel.

Putra, D. W., Nugroho, A. P., \& Puspitarini, E. W. (2016). Educational games as learning media for early childhood education. Jurnal Informatika Merdeka Pasuruan.

Ramadoni, W., \& Imron, A. K. (2016). Principal leadership in efforts to improve teacher performance multi case study in Sabilillah Islamic education and Sdn. Educational Journal.

Suryono, Y., \& Fauziah, P. Y. (2015). Model of character education for children through non-formal "mother schools" in rural areas. Journal of Educational Research and Evaluation.

Unity Asset Store. (2014). Asset store. Retrieved from https://doi.org/https://www.assetstore.unity3d.com/en/.

Ziegler, C., Bremer, E., \& Krämer, R. (2010). The BCCT family of carriers: From physiology to crystal structure. Molecular Microbiology, $78(1), 13-34$. 